\title{
Mapping specular hematite ore beneficiation routes to industrial application standards
}

Rudarsko-geološko-naftni zbornik

(The Mining-Geology-Petroleum Engineering Bulletin) UDC: $622: 69$

DOI: 10.17794/rgn.2022.1.1

Original scientific paper

\author{
Alireza Abedi' ${ }^{1}$, Ataallah Bahrami' ${ }^{1}$, Sajjad Chehreghani ${ }^{1}$, Masoud Ghadri' ${ }^{2}$, Fatemeh Kazemi ${ }^{3}$ \\ ${ }^{1}$ Department of Mining Engineering, Faculty of Engineering, Urmia University, Urmia - Iran. \\ ${ }^{2}$ Mining Engineer of Gozal-Belagh Mine - Iran. \\ ${ }^{3}$ PhD student of mineral processing, Faculty of Engineering, University of Kashan, Kashan - Iran.
}

\begin{abstract}
The purpose of this study is to determine the appropriate method for micaceous iron ore processing and production perindustrial application standards. After identifying the characteristics of the samples (with XRF, XRD, mineralogical analyzes), gravity and magnetic separation tests were carried out. Quartz and hematite are the main minerals of micaceous hematite ores. Silica grade as the major impurity varies from $10 \%$ to $68 \%$. The total iron content of the samples also varies from $15 \%$ to $62 \%$. A jig and shaking table did not provide a good result in micaceous hematite beneficiation to achieve the standard of its specific applications. Gravity concentration by the spiral in the size range of -200 and -300 $\mu \mathrm{m}$ has led to the production of iron concentrates with a grade of $62.34 \%$ and $64.84 \%$, respectively. The recovery values for the two experiments are $13.50 \%$ and $12.60 \%$, respectively. Therefore, the spiral did not provide a good result in the micaceous iron ore beneficiation. High-intensity magnetic separation $(1.2 \mathrm{~T})$ has resulted in a product with a grade and recovery of $65.98 \%$ and $88.35 \%$, respectively. The experimental design utilizing the Taguchi method considering the increasing of grade or recovery priority indicated that for micaceous iron beneficiation with a priority of recovery increasing, the feeder frequency, roll speed, and adjustable gate angle should be at $6.5 \mathrm{~Hz}, 95 \mathrm{rpm}$, and $20^{\circ}$, respectively. However, for micaceous iron beneficiation with a priority of grade increasing, the feeder frequency, roll speed, and adjustable gate angle should be at $2.5 \mathrm{~Hz}, 135 \mathrm{rpm}$, and $60^{\circ}$, respectively.
\end{abstract}

\section{Keywords:}

Specularite; micaceous iron oxide; magnetic separation; gravity separation; Taguchi

\section{Introduction}

Iron oxy-hydroxides play an important role in a variety of disciplines such as mineralogy, geology, etc. (Cambala et al., 2017). Micaceous iron oxide (MIO), or specular hematite, is an iron oxide mineral with the chemical formula of $\mathrm{Fe}_{2} \mathrm{O}_{3}$, and a gray to reddish-brown color (Tian et al., 2017). Micaceous hematite deposits are formed during the solution - deposition processes and in association with the oxidation and allotropism of magnetite (Wang et al., 2017). These reserves are found as lateral weathering profiles as a result of the iron supergene enrichment during the Cretaceous to Tertiary period. In general, with the oxidation of primary reserves and also due to hydrothermal deposition, huge reserves of hematite have been formed (Guba, 1982; Villalba et al., 2010). During these processes, magnetite and hematite are converted to each other by decreasing oxygen fugacity and increasing instability according to Equation 1. This reaction takes place in the superficial parts of the magnetite veins. In this case, the formed hematite

Corresponding author: Sajjad Chehreghani

s.chehreghani@urmia.ac.ir minerals appear as coarse crystals and relatively short specularite, causing a directional fabric in the rock. Oriented specularite minerals in the veins typically appear in the pressure shadows and margins of quartz and feldspar alkaline porphyroclasts (Hackspacher and PC, 1979; Lagoeiro, 1998).

$$
4 \mathrm{Fe}_{3} \mathrm{O}_{4}+\mathrm{O}_{2} \rightarrow 6 \mathrm{Fe}_{2} \mathrm{O}_{3}
$$

Due to the planar structure of micaceous hematite minerals, these minerals are used in certain industries, such as welding electrodes, paint and coating, brake pads, etc. Therefore, understanding the mineralogical and geochemical properties of this type of iron ore have been studied by various researchers (Tamboura et al., 2013; Yang et al., 2016; Franco et al., 2016; Tanriverdi et al., 2018). MIOs are non-toxic, chemically inert, with mica-like planar crystals, which are insoluble in water, organic and alkaline solvents, and slightly soluble in concentrated hydrochloric acid. Table $\mathbf{1}$ presents the physical properties of MIO. As mentioned, MIO is mainly used in the pigment industry as a coating as well as an alternative to iron powder in welding electrodes (Ravi et al., 2015). However, the use of MIO as a pig- 
Table 1: Physical properties of MIO and technical specifications, for use in the coating and electrode industries

\begin{tabular}{|c|c|c|c|c|c|c|c|}
\hline \multicolumn{8}{|c|}{ The physical properties of MIO } \\
\hline Form & & $\begin{array}{l}\text { Boiling } \\
\text { point }\left({ }^{\circ} \mathrm{C}\right)\end{array}$ & $\begin{array}{l}\text { Melting } \\
\text { point }\left({ }^{\circ} \mathrm{C}\right)\end{array}$ & $\begin{array}{l}\text { Volatile matter } \\
(\%)(\text { ISO } 787 / 2)\end{array}$ & $\begin{array}{l}\text { Loss on ignition } \\
(\mathrm{LOI}) \text { at } 800^{\circ} \mathrm{C}(\%)\end{array}$ & $\begin{array}{c}\text { Volumetric density } \\
\left(\mathrm{g} / \mathrm{cm}^{3}\right)(\text { DIN53466) }\end{array}$ & $\begin{array}{c}\text { Apparent } \\
\text { density }\left(\mathrm{g} / \mathrm{cm}^{3}\right)\end{array}$ \\
\hline Powder & & 1000 & 1500 & $<0.3$ & $<1$ & 1.7 & $4.5-8$ \\
\hline \multicolumn{8}{|c|}{ Technical specifications of MIO for use in coating and pigment industries and welding electrodes } \\
\hline $\begin{array}{l}\text { Thin flat } \\
\text { particles } \\
\text { (wt. \%) }\end{array}$ & $\begin{array}{l}\text { Density } \\
\left(\mathrm{g} / \mathrm{cm}^{3}\right)\end{array}$ & $\begin{array}{c}\text { Particle } \\
\text { size }(\mathrm{mm})\end{array}$ & $\begin{array}{l}\text { LOI (wt. } \\
\%)\end{array}$ & $\mathrm{Al}_{2} \mathrm{O}_{3}$ (wt. \%) & $\mathrm{SiO}_{2}$ (wt. \%) & $\mathrm{Fe}_{2} \mathrm{O}_{3}$ (wt. \%) & $\mathrm{Fe}($ wt. \%) \\
\hline$>70$ & 4.8 & $<0.1$ & $<1$ & $<2$ & $<2$ & $>85$ & $>65$ \\
\hline
\end{tabular}

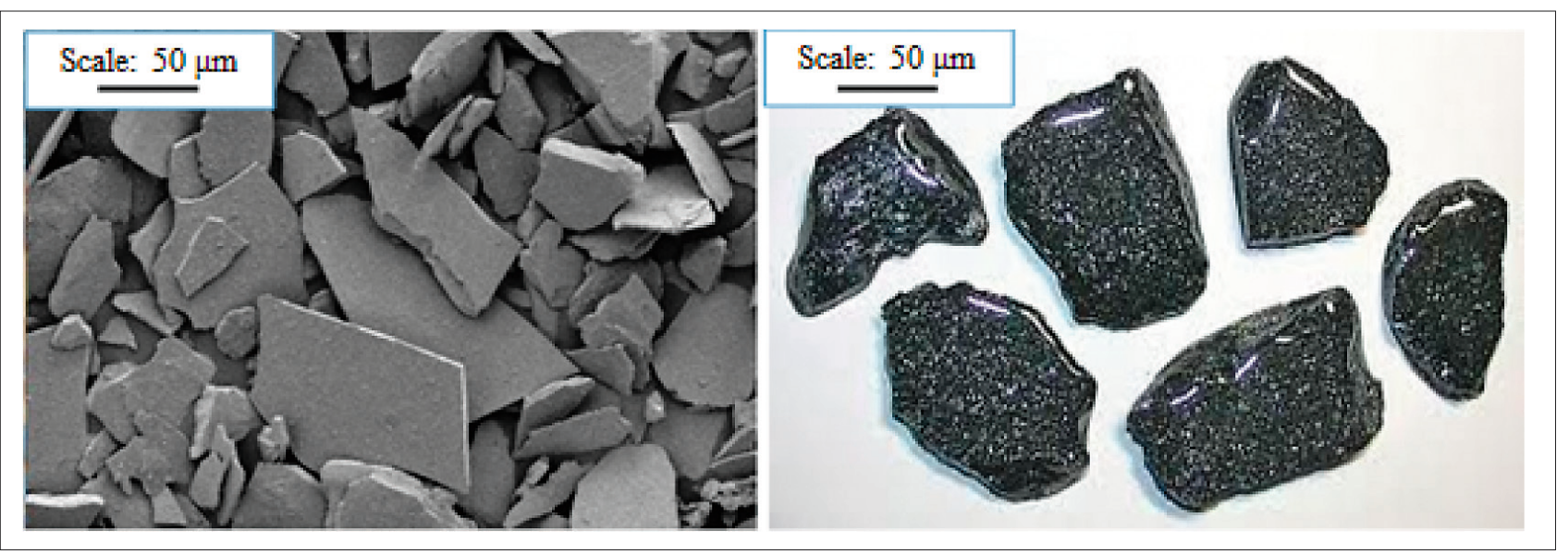

Figure 1: Macroscopic (right) and microscopic - BSE photomicrograph (left) images of MIO

ment to produce paints that are utilized in protecting the surfaces of metallic structures is more important. In this mineral, the pigment particles are directed in parallel layers on the surface and protect the surfaces against corrosive substances and water (Cornell and Schwertmann, 2003; Kalenda et al., 2004; Baena et al., 2009). This mineral has been successfully used in the preparation of alkyd, epoxy, polyurethane paints, and chlorine impregnated coatings, separate or in combination with other materials. According to ISO10601, the $\mathrm{Fe}_{2} \mathrm{O}_{3}$ content required for the application of MIO pigments is more than $85 \%$. The technical specifications of MIO for use in coatings, pigments, and welding electrodes are given in Table 1. Figure 1 also shows images of MIO.

Numerous studies have been conducted on the use of micaceous iron with these specific applications. Amini and Sarabi (2010) conducted a study to investigate the properties of epoxy-polyamine protective coating reinforced with glass flake pigment in the presence of MIO pigment. According to the results, the presence of MIO pigment along with glass flake pigment increases corrosion, wear resistance of the coating, and reduces the adhesion and the resistance under the salt spray test conditions. Kakaei et al. (2012) conducted a study on the effect of MIO on the corrosion protection behavior of zinc-rich aqueous silicate - based coatings. The results indicate that although the mentioned alternative reduced the cathodic protection period of steel due to the zinc- rich coating, it led to significant anti-corrosion properties in the salt spray test. The results show that MIO can be used to control the activity rate of zinc-rich coatings. Bakhshi and Zaarei (2015) conducted a study on the replacement of $\mathrm{MIO}$ with zinc particles in terms of the chemical and mechanical properties of zinc-rich epoxy coatings. The test results showed that the replacement of up to $40 \%$ of formulation weight values with MIO pigment reduced the reactivity of the resulting coating and increased the cathodic protection period by $40 \%$. Erfaghi et al. (2017) conducted a study to evaluate the anticorrosion properties due to the presence of MIO in the formulation of gas transmission pipeline primers based on synthetic rubber. The results of electrochemical tests indicate improved corrosion resistance properties of primers containing lower percentages of MIO pigments compared to non-pigmented primers.

Micaceous iron extracted from the mine contains a variety of compounds and gangue minerals. In order to use the MIO in the industries listed above with the required standard characteristics, it must be subjected to beneficiation processes. As with other types of iron ores, gravity concentration methods, magnetic separation, and flotation processes are considered as the most commonly proposed and applicable processes for MIO beneficiation. Various studies have been conducted in this field. Wang et al. (2011) conducted a study on an MIO reserve containing $35 \% \mathrm{Fe}$, using sequential processes of 


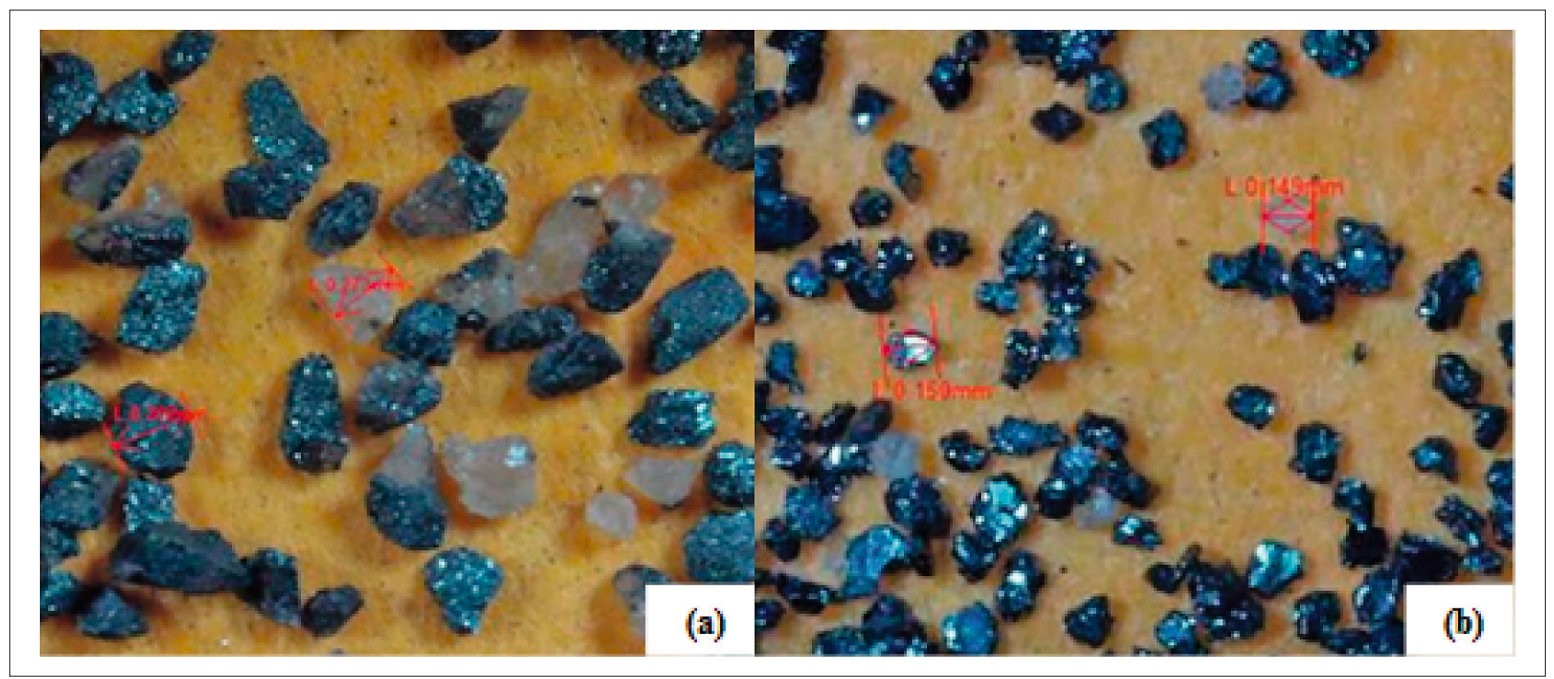

Figure 2: Microscopic images of MIO - size fractions of a) $200-300 \mu \mathrm{m}$ and b) $150-200 \mu \mathrm{m}$ (with $\times 100$ magnification)

high-intensity magnetic separation and reverse flotation. Finally, concentrates with a grade of $66.62 \%$ iron and weight recovery of $30.65 \%$ have been obtained. Ravi et al. (2015) conducted a study on an ore sample with $52.44 \%$ iron using a shaking table and a high-intensity magnetic separator (HGMS); that led the Fe grade in the resulting concentrate to rise up to $67.80 \%$. Vapur and Top (2016) produced concentrates containing $92.47 \%$ $\mathrm{Fe}_{2} \mathrm{O}_{3}$ with an efficiency of $69.91 \%$ utilizing a wet magnetic separator with a magnetic field strength of $0.6 \mathrm{~T}$ from an MIO sample containing $62.94 \% \mathrm{Fe}_{2} \mathrm{O}_{3}$. Since pyrite particles are recovered with iron oxide in conventional gravity and magnetic processing methods, the presence of pyrite particles in MIO ores causes problems in the conventional separation methods (Zheng et al., 2017; Tanriverdi et al., 2018). In the present study, the application of gravity and magnetic separation methods in MIO ore processing has been investigated. In this regard, by determining the appropriate processing method and also determining the optimal conditions of the relevant process, MIO concentrates are produced per the standards of coating paints, welding electrodes, and brake pads.

\section{Materials and Methods}

To investigate the possibility of producing concentrates of micaceous iron per the welding electrodes industry and coating paints' application standards, a sample weighing $800 \mathrm{~kg}$ (for pilot and laboratory scale tests) was obtained via the bulk sampling method from the Gozal-Belagh Mine-Iran and sent to the laboratory for further testing. Guzel Bolagh mineral index with geographical coordinates of $46^{\circ} 37^{\prime}$ to $46^{\circ} 42^{\prime} \mathrm{E}$, longitude and $36^{\circ} 24^{\prime}$ to $46^{\circ} 31^{\prime} \mathrm{N}$, latitude, is located in the south of the West Azerbaijan province (Shahin-dezh city). The proven reserve is about 250000 tons, and the probable reserve is about 700000 tons. Considering that MIO in this area can be seen as veins or veins between magnetite and hematite rocks; the best method for sampling these veins is mass sampling. In bulk sampling, via sample selection and data collection, the results are determined by considering the error values for a large population. The selected sample is greatly representative of the large population and the findings from the sample can be generalized to the larger population with an acceptable amount of error.

\subsection{Physical and chemical characterization of the micaceous hematite ores}

Objective observations indicated the presence of ores with different appearances in the micaceous hematite ore. To identify the properties of the studied micaceous hematite ores from the perspective of chemical composition as well as the mineralogical structure, a manual sorting method was carried out to prepare various samples. Subsequently, chemical content determination analyses were performed using X-ray fluorescence (XRF) on selected samples. Based on the results of these analyses, the iron content in the studied micaceous hematite ores varied from $15-62 \%$. Silica is also the major impurity in the studied micaceous hematite ore, the grade of which varied from $10-68 \%$ for different samples. In the next step, degree of liberation studies was conducted on a micaceous hematite sample in different size fractions using a digital microscope with $\times 100$ magnification capability. Based on the results, the degree of liberation in this sample was about $200 \mu \mathrm{m}$. According to microscopic images shown in Figure 2, it can be stated that about $90 \%$ of liberated particles are less than $200 \mu \mathrm{m}$.

Based on the results obtained from the degree of liberation studies and for additional studies to identify disturbing and associated gangue minerals, mineralogy studies (XRD) and chemical composition analysis (XRF) were carried out on iron oxide samples in two size fractions of -300 and $-200 \mu \mathrm{m}$ (it should be noted 
Table 2: Results of XRF and XRD analyzes of MIO sample in two size fractions of -200 and $-300 \mu \mathrm{m}$

\begin{tabular}{|l|c|c|c|c|c|c|c|}
\hline \multicolumn{7}{|c|}{ XRF } \\
\hline Size fraction $(\mu \mathrm{m})$ & $\mathrm{SiO}_{2}$ & $\mathrm{Al}_{2} \mathrm{O}_{3}$ & $\mathrm{BaO}$ & $\mathrm{CaO}$ & $\mathrm{Fe}(\mathrm{T})$ & $\mathrm{MgO}$ & LOI \\
\hline-300 & 56.19 & 1.93 & 2.40 & 0.99 & 23.56 & 0.52 & 0.13 \\
\hline-200 & 51.82 & 0.35 & 0.80 & 0.58 & 31.11 & 0.06 & 1.10 \\
\hline \multicolumn{7}{|c|}{ XRD } \\
\hline Size fraction $(\mu \mathrm{m})$ & Quartz & Hematite & Chlorite & Calcite & Muscovite & Barite & Geothite \\
\hline-300 & 53 & 29 & 2 & 2 & 4 & 4 & 5 \\
\hline-200 & 50 & 42 & 1 & 1 & 1 & 1.5 & 3 \\
\hline
\end{tabular}

that the measurement accuracy in XRF analysis is $0.05 \%$ ). The results of these analyses are presented in Table 2. According to Table 2, in particle size fraction of $-200 \mu \mathrm{m}$, the amount of total iron content of the sample compared to the fraction of $-300 \mu \mathrm{m}$, increased by about $8 \%$. The results of X-ray diffraction (XRD) analyses indicate that quartz and hematite are the major constituent minerals of micaceous hematite ores; and with decreasing particle size, the amount of these two minerals increased in terms of volume percentage. Chlorite, calcite, muscovite, barite, and goethite are other identified phases in the deposit, the total volume percentage of which was less than $17 \%$.

\subsection{Comminution approach for ore sample size reduction}

According to Table 1, the MIO used in the raw materials for welding electrodes and coating paints has a particle size of less than $100 \mu \mathrm{m}$. For this purpose, the ore samples must be crushed to the desired size fraction. On the other hand, according to microscopic studies, a suitable degree of liberation for micaceous hematite is less than $200 \mu \mathrm{m}$. Therefore, after the crushing processes (by jaw and roller crushers), the grinding of the sample was carried out in a ball mill. Due to their elasticity and lamellar shape, micaceous hematite mineral particles face challenges, such as temporary deformation, absorption of comminution energy, and thus reduction of process efficiency during comminution. Therefore, to study and compare the wet and dry milling processes of MIO, laboratory-scale comminution experiments were performed, and the results were analyzed using particle size distribution functions. Figure 3 shows the sieve analysis diagrams of feed entering the mill, and milled products by the dry and wet method. According to the results, wet milling products with $\mathrm{d}_{80}=100 \mu \mathrm{m}$ were finer than dry milling products with $\mathrm{d}_{80}=120 \mu \mathrm{m}$, in the same milling duration. Depending on the shape, the $\mathrm{d}_{50}$ of feed entering the mill was $500 \mu \mathrm{m}$, and all of the particles were less than $1000 \mu \mathrm{m}$. The $\mathrm{d}_{50}$ values for wet millings and dry millings are 38 and $41 \mu \mathrm{m}$, respectively. The $\mathrm{d}_{80}$ values are 100 and $120 \mu \mathrm{m}$ for wet and dry milling methods, respectively. The particle size distribution in the wet milling method indicates a faster decrease in the average particle size $\left(d_{50}\right)$ than the dry one. This is due to the dif-

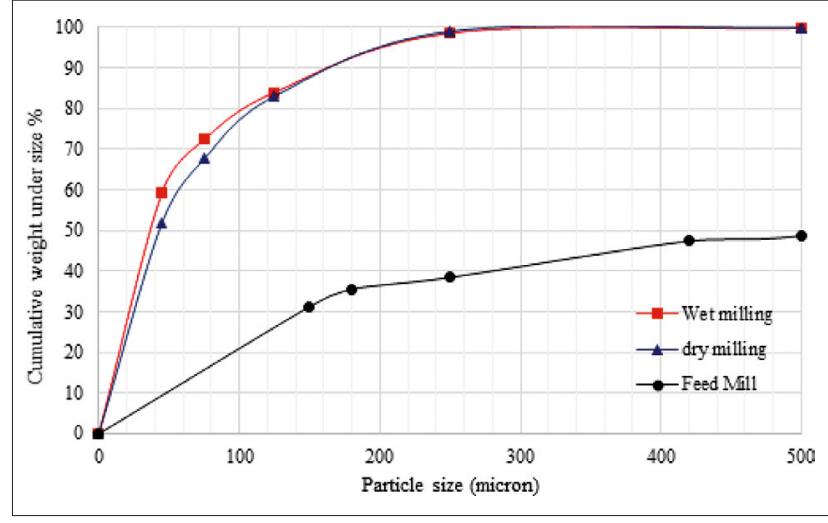

Figure 3: Particle-size distribution diagrams of feed, wet and dry milling products

ference in fracture energy and the mill environment in wet and dry conditions. Given that, if the elastic strain energy is proportional to the square of strength, the energy in wet milling is approximately $20 \%$ less than in dry milling. The presence of water has rapidly increased the pulp viscosity for wet milling, where a layer of particles begins to deposit in the inner wall of the mill. As a result, the contact efficiency between the ball and the particle is significantly reduced, which reduces the failure in wet milling.

\subsection{Mineral processing tests and determination of optimal concentration conditions}

\subsubsection{Gravity separation tests}

Based on chemical composition analyses and microscopic studies, silica and hematite are the major constituent minerals of the studied MIO ore. Due to the difference in specific gravity between micaceous iron ore $(5.2$ - 5.3) and the main tailings associated with it, namely silica (15.87), a series of gravity separation tests including jig, shaking table, and spiral were performed. Separation by jig for particle size fraction larger than $2 \mathrm{~mm}$ and shaking table for size fractions of $0-0.5,0.5-1$, and $1-2$ $\mathrm{mm}$ did not provide the desired results in the final concentration of the studied MIO ore (see Table 3). However, the use of jig for pre-processing of low-grade and coarse-grained micaceous hematite ore $(>6 \mathrm{~mm})$ is recommended due to the effective separation of hematite 
from silica by jig. Spiral separation experiments were performed by classifying the sample into two size fractions of -300 and $-200 \mu \mathrm{m}$, and separation experiments on the pilot-scale were performed for each one. The size fractions tested were selected based on spiral efficiency in this range, degree of liberation studies, chemical analyses, and dimensional range of raw materials required for specific MIO applications. In these experiments, the feed rate was constant and the solid pulp percentage was $15 \%$.

Table 3: Gravity separation tests for concentration MIO

\begin{tabular}{|l|l|l|}
\hline Gravity separation & Size fractions $(\mathbf{m m})$ & Scale \\
\hline Shaking Table & $0-0.5,+0.5-1,+1-2$ & Lab scale \\
\hline Jig & +2 & Lab scale \\
\hline Spiral & $-0.2,-0.3$ & Pilot scale \\
\hline
\end{tabular}

\subsubsection{Magnetic separation tests and determination of optimal separation conditions}

A dry magnetic separation method was performed on the studied MIO sample. To carry out preliminary studies in association with magnetic concentration, the sample was categorized into four size fractions of 1-6.35, $0-4.75,0-2$, and $0-1 \mathrm{~mm}$, and magnetic separation was performed on each size fraction utilizing a $1.2 \mathrm{~T}$ magnetic separator. Table 4 shows the specifications of the utilized magnetic separator. In all experiments, the angle of an adjustable gate between the concentrate and the tail was $60^{\circ}$ towards the concentrate, and the roll speed was $135 \mathrm{rpm}$. In the next step, based on the results of the initial magnetic separation experiments, to determine the optimal separation conditions, the experiments were designed by the Taguchi method, and Minitab software was used for systematic analysis of the results. In conducting experiments, determining variable and dependent parameters and designing experiments is a key step. Considering the three parameters mentioned in Table 5, three levels for each variable based on the best possible condition in the maximum, minimum, and average value of these two levels were selected. Based on this, the de-

Table 4: Specifications and information of $1.2 \mathrm{~T}$ magnetic separator

\begin{tabular}{|l|l|}
\hline Device name & Roll magnetic separator \\
\hline Manufacturing company & Aksa Magnet \\
\hline Separation method & Dry \\
\hline Magnetic intensity & $1.2 \mathrm{~T}$ \\
\hline Controllable parameters & $\begin{array}{l}\text { Concentration angle, Roll speed, } \\
\text { Feeding rate }\end{array}$ \\
\hline Device specifications & $\begin{array}{l}\text { Roll length: } 200 \mathrm{~mm} \\
\text { Roll thickness: } 0.1-5 \mathrm{~mm} \\
\text { Capacity: Depending on the type } \\
\text { and specifications of the material } \\
\text { Roll speed: } 40-400 \mathrm{rpm}\end{array}$ \\
\hline
\end{tabular}

Table 5: Parameters and levels of each magnetic separation experiments designed by the Taguchi method

\begin{tabular}{|l|l|l|l|}
\hline No. & Roll speed (rpm) & Feeding Rate $(\mathbf{H z})$ & Angle $\left(^{\circ}\right)$ \\
\hline 1 & 135 & 2.5 & 20 \\
\hline 2 & 135 & 4.5 & 40 \\
\hline 3 & 135 & 6.5 & 60 \\
\hline 4 & 115 & 2.5 & 40 \\
\hline 5 & 115 & 4.5 & 60 \\
\hline 6 & 115 & 6.5 & 20 \\
\hline 7 & 95 & 2.5 & 60 \\
\hline 8 & 95 & 4.5 & 20 \\
\hline 9 & 95 & 6.5 & 40 \\
\hline
\end{tabular}

sign by the Taguchi L18 array method has led to the proposal of 9 experiments. The parameters and values of each experiment are given in Table 5.

\section{Results and Discussion}

\subsection{Micaceous iron processing using gravity separation methods}

The jig and shaking table methods did not provide the desired results in the concentration of micaceous hematite ores from the process efficiency as well as product production per the standards of its specific applications, standpoint. Investigation of the possibility of studied MIO ore concentration by the spiral in two size fractions of -300 and $-200 \mu \mathrm{m}$, has led to the results according to Table 6. The first spiral test was performed on a sample in the size fraction of $-300 \mu \mathrm{m}$ with a total iron grade of $23.56 \%$. Separation by spiral for this sample were led to the production of concentrate, tailings, and intermediate products with an iron grade of $64.84 \%, 25.84 \%$, and $37.25 \%$, respectively. The second spiral test was performed on a sample in the size fraction of $-200 \mu \mathrm{m}$ with an iron grade of $31.11 \%$. The iron content of the concentrate obtained from this experiment was $62.34 \%$, the grade of the intermediate product and its tailings were $32.32 \%$ and $17.96 \%$, respectively. The spiral recovery of this size fraction increased by only about one percent relative to the particles in the $-300 \mu \mathrm{m}$ size fraction. The grade of concentrate increased with increasing particle size, and the recovery value decreased with increasing particle size. It can be said that the separation by spiral is also dependent on the economy and metals market conditions. If only a high-grade concentrate is considered, a spiral may be appropriate; however, since the main purpose of mineral processing is to obtain concentrates with a high grade and recovery, the use of spirals does not seem to be an efficient method and can be used as a pretreatment or in combination with variety of gravity methods.

Considering the iron, silica, and alumina grade of the spiral concentrates in Table 6, and comparing them with 
Table 6: Results of spiral experiments in micaceous iron ore concentration for two size fractions of -200 and $-300 \mu \mathrm{m}$

\begin{tabular}{|c|c|c|c|c|}
\hline \multirow{2}{*}{$\begin{array}{l}\text { Feed } \\
\text { particle size } \\
(\mu \mathrm{m})\end{array}$} & \multicolumn{3}{|c|}{ Grade (\%) } & \multirow{2}{*}{$\begin{array}{l}\text { Iron } \\
\text { recovery }(\%)\end{array}$} \\
\hline & $\mathrm{Fe}(\mathrm{T})$ & $\mathrm{SiO}_{2}$ & $\mathrm{Al}_{2} \mathrm{O}_{3}$ & \\
\hline-200 & 62.34 & 30.74 & 0.19 & 13.50 \\
\hline-300 & 64.84 & 32.13 & 0.23 & 12.60 \\
\hline
\end{tabular}

the MIO application standards used in the manufacture of coating paint and welding electrode, it can be said that the spiral concentrate for $-300 \mu \mathrm{m}$ feed is a more suitable product from the iron grade point of view (the standard amount of iron is more than $65 \%$ ). In both tests, the alumina grade is in the optimal range (less than $2 \%$ ), but the silica grade is much higher than the standard limit $(2 \%)$. To investigate the effect of mineral processing in the production per standards, pigment-making experiments were performed on the feed and concentrate of the -300 $\mu \mathrm{m}$ spiral test. For each of the feed and concentrate samples, the paint manufacturing was performed separately. The pigments were poured in $40 \mathrm{~g}$ of solvent (industrial alcohol) and mixed for 30 minutes to obtain the initial solution. Then 40 and $20 \mathrm{~g}$ of resin and hardener were added to the solution, respectively, and the solution was mixed again for 1-2 hours until the raw materials were mixed evenly and the desired color was obtained. The paint produced by the spiral concentrate is more uniform and of better quality and has a higher solubility during manufacturing than the paint produced by the spiral feed. The poor quality of the paint produced by the feed is due to the presence of larger amounts of silica gangue particles as well as fine hematite particles. In general, by separating with spiral, in addition to removing silica, fine particles are also washed and a better product can be produced.

\subsection{Micaceous iron processing using magnetic separation method}

Magnetic separation in the presence of a $1.2 \mathrm{~T}$ magnetic field for the three size fractions of the MIO ore provided the results shown in Table 7. According to the results, the weight percentage of the mineral recovered to the concentration decreased with increasing particle size, and consequently, the iron content increased. A comparison of the ratio of concentration for different size fractions shows that the $2 \mathrm{~mm}$ size fraction has the

Table 7: Results of magnetic separation experiments in micaceous iron ore concertation for different size fractions

\begin{tabular}{|l|l|l|l|l|}
\hline \multirow{2}{*}{$\begin{array}{l}\text { Particle size } \\
(\mathbf{m m})\end{array}$} & \multicolumn{2}{|l|}{ Grade $\mathbf{( \% )}$} & \multicolumn{2}{l|}{$\begin{array}{l}\text { Iron } \\
\text { recovery } \mathbf{( \% )}\end{array}$} \\
\cline { 2 - 5 } $\mathbf{F e}_{\mathbf{2}} \mathbf{O}_{\mathbf{3}}$ & $\mathbf{S i O}_{\mathbf{2}}$ & $\mathbf{A l}_{\mathbf{2}} \mathbf{O}_{\mathbf{3}}$ & rov \\
\hline $0-1$ & 59.77 & 36.01 & 0.7 & 95.27 \\
\hline $0-2$ & 60.79 & 36.01 & 0.63 & 94.37 \\
\hline $0.75-4$ & 65.98 & 31.91 & 0.37 & 88.35 \\
\hline $1.35-6$ & 65.80 & 32.57 & 0.18 & 75.25 \\
\hline
\end{tabular}

highest ratio of concentration value of 1.88. In addition, according to the results of XRF analysis, with increasing particle size, the amount of tailings silica grade of different size fractions has decreased. This means that by reducing the particle size, the magnetic separator has a better efficiency in removing silica particles. This trend is also observed concerning other available tailings such as $\mathrm{Al}_{2} \mathrm{O}_{3}$.

Figure 4 shows bar graphs of $\mathrm{Fe}_{2} \mathrm{O}_{3}$ grade and recovery against particle size for magnetic separation experiments. According to the figure, with an increase in particle size, the recovery is reduced and the iron grade is increased. Iron grade values increased with a moderate slope with an increase in particle size, while the reduction slope of the recovery decreased with an increase in size (especially between the fractions of $0-4.75$ and 1-6.35 mm). In general, according to the results of magnetic separation experiments with a magnetic intensity of 1.2 $\mathrm{T}$ that have been performed on different size fractions of MIO, the best separation conditions occurred when a grade of $65.98 \%$ and recovery of $88.35 \%$ for the size fraction of $0-4.75 \mathrm{~mm}$ were selected.

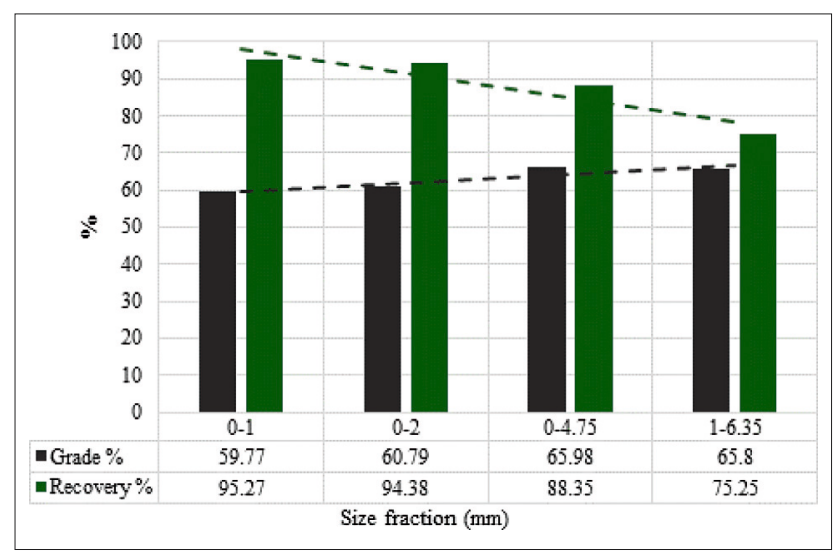

Figure 4: Grade and recovery diagrams against particle size of magnetic separation in different size fractions

\subsection{Determination of the optimal conditions for MIO concentration by magnetic method}

According to the results of the previous two sections, it can be stated that magnetic separation has a more appropriate result in $\mathrm{MIO}$ ore processing considering the grade and recovery of product. In this regard, in designing experiments by the Taguchi method, an attempt has been made to determine the optimal operating conditions for MIO processing by the high-intensity magnetic method. Considering the three parameters of roll speed, feeder frequency, and angle of the adjustable gate, and three levels for each variable based on the best possible condition in the maximum, minimum, and average values of these two levels were selected. Based on the results, the highest iron content of $40.94 \%$ was obtained in the conditions of roll speed of $135 \mathrm{rpm}$, feeder frequency of $6.5 \mathrm{~Hz}$ and the adjustable gate angle of $60^{\circ}$; while the optimal conditions 


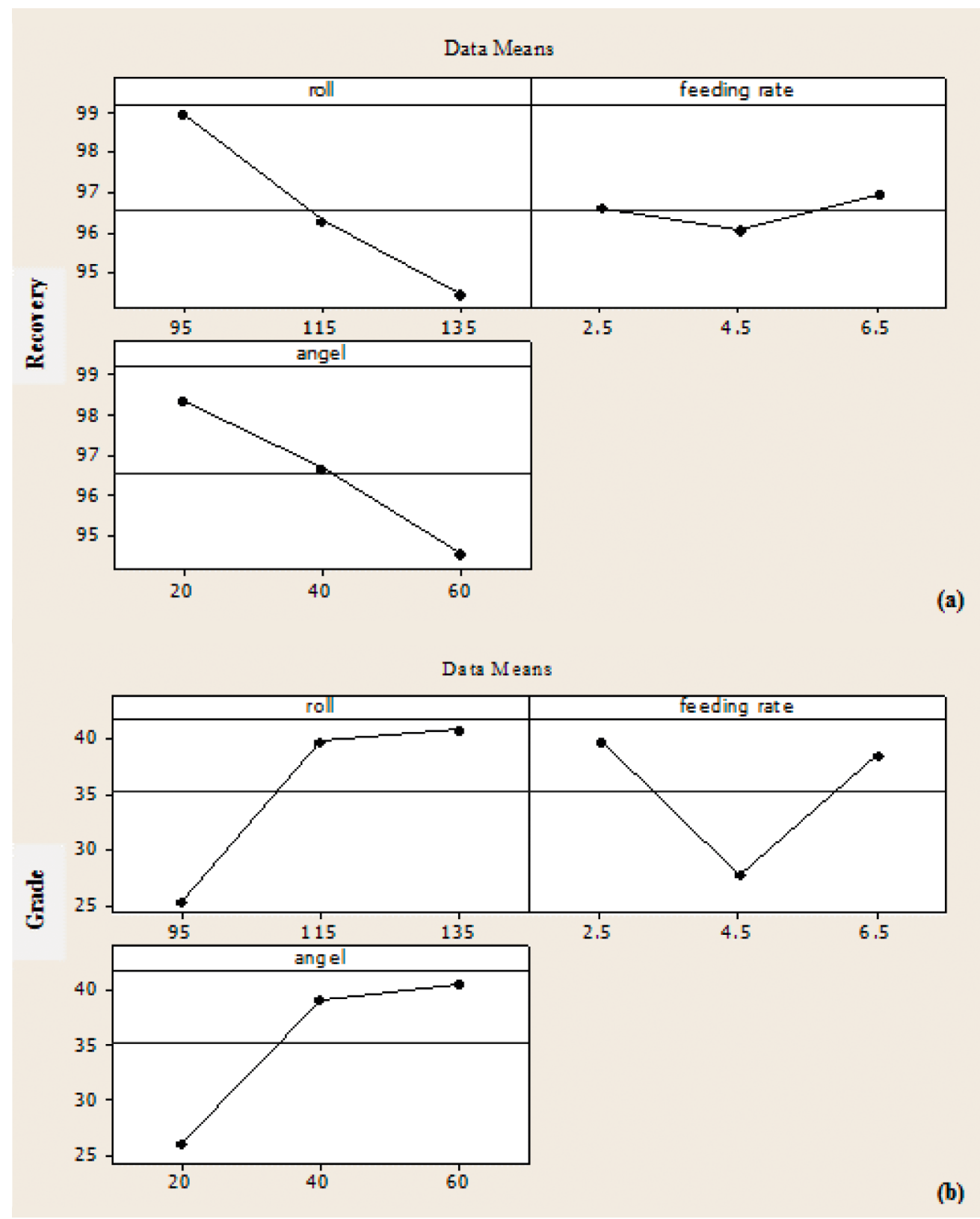

Figure 5: Dependency diagrams for a) Recovery and b) Grade with the parameters of magnetic separation tests

for obtaining the maximum value of recovery were at a roll speed of $95 \mathrm{rpm}$, feeder frequency of $4.5 \mathrm{~Hz}$, and adjustable gate angle of $20^{\circ}$. Graphs of recovery and grade relationships with the levels of operational variables of the experiments are shown in Figure 5. According to the figure, by changing the levels of the roll speed and the adjustable gate angle parameters, a change in recovery occurred with a steep slope. As the levels of both variables increased, the recovery value decreased by about $4 \%$. Recovery of about $99 \%$ was achieved at a roll speed of 95 $\mathrm{rpm}$ and an adjustable gate angle of $20^{\circ}$. Increasing the feeder frequency did not have a significant effect on the recovery. Regarding grade, the trend is reversed and with an increase in the roll speed and the adjustable gate angle, the grade value increased.

\section{Conclusions}

The use of micaceous iron ores in the raw materials of coating paints and welding electrodes is dependent upon processing operations and product production per the standards of these industries. In the first stage, it can be said that the use of the manual sorting method as an effective step for the initial separation of micaceous iron ore will be a practical preprocessing method. The gravity concentration of micaceous hematite by spiral, due to the need to crush the primary feed to dimensions less than $300 \mu \mathrm{m}$ and also low recovery, is not properly justified. By magnetic separation of micaceous hematite ores in coarse-grained $(4.75 \mathrm{~mm})$ size ranges under a high-intensity magnetic field $(1.2 \mathrm{~T})$, products with a grade of more 
than $65 \% \mathrm{Fe}_{2} \mathrm{O}_{3}$ and recovery of more than $85 \%$ can be produced. To produce per the standards of paint and electrode industries (particle size of $-100 \mu \mathrm{m}$, total iron grade of more than $65 \%$, and silica grade of less than $2 \%$ ), the magnetic separation concentrate can be crushed to the separation cut-point of the studied micaceous hematite, i.e. $200 \mu \mathrm{m}$, and then re-concentrated with wet high-intensity magnetic methods, and even flotation.

\section{References}

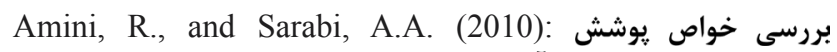

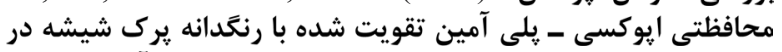
(Study of the properties of an Epoxy-Polyamine protective coating reinforced with glass flake pigment in presence of micaceous iron oxide pigment). Journal of Amir-kabir University, 40, 2, 24-32. (In Persian: with English abstract).

Baena, O.R., Pinilla, A.F., and Bello, S.D. (2009): Characterization and concentration of specularite as natural pigment for to manufacture anticorrosives paints. Revista Mexicana De Fisica, 55, 1, 123-126.

Bakhshi, N., and Zaarei, D. (2015): بررسى اثر جايكزينى أروى

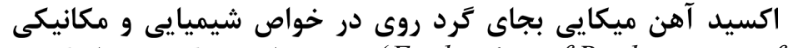
يوشش دراى زينك ريج إيوكس وكسى (Evaluation of Replacement of zinc by Micaceous iron oxide in zinc Rich Epoxy coatings and its effect on mechanical and chemical properties). Journal of advanced material \& novel coating, 17, 5, 1428. (In Persian: with English abstract). https://dx.doi.org/ AMNC.2016.5.17.5.

Cornell, R.M., and Schwertmann, U. (2003): The iron oxides: structure, properties, reactions, occurrences and uses. John Wiley \& Sons, 38 p.

Cambala, M., Hruškova-Hasan, M., and Mileusnić, M. (2017): A comparison of diff erent rinsing methods upon selective dissolution of iron (oxy) hydroxides in soils/sediments. Rudarsko-geološko-naftni zbornik, 32, 2, 9-14. https://doi. org/10.17794/rgn.2017.2.2.

Erfaghi, H., Farzam, M., Zaarei, D., Danaee, I., and Abol-

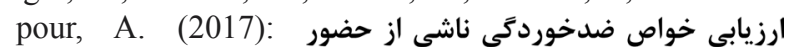

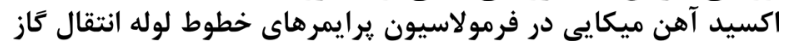

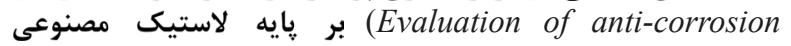
properties of MIO pigments in the formulation of synthetic rubber based primer used in gas pipeline). Journal of new materials, 8, 29, 109-120. (In Persian: with English abstract). https://dorl.net/dor/20.1001.1.22285946.1396.8.2 9.9.8.

Franco, F., Benítez-Guerrero, M., Gonzalez-Triviño, I., PérezRecuerda, R., Assiego, C., Cifuentes-Melchor, J., and Pascual-Cosp, J. (2016): Low-cost aluminum and iron oxides supported on dioctahedral and trioctahedral smectites: A comparative study of the effectiveness on the heavy metal adsorption from water. Applied Clay Science, 119, 321332. https://doi.org/10.1016/j.clay.2015.10.035.

Guba, I. (1982): Tektonik, Texturen und Mineralogie der präkambrischen Eisenerze und Nebengesteinsserien der Lagerstätte Morro Agudo im NE des Quadrilátero Ferrífero/Minas Gerais, Brasilien. Doctoral dissertation, Technische Universität Clausthal, 58 p.
Hackspacher, P.C., and PC, H. (1979): Strukturelle und texturelle Untersuchungen zur internen Deformation des Eisenreicherzkörpers der Grube" Aguas Claras" bei Belo Horizonte/Minas Gerais. Brasilien, 37 p.

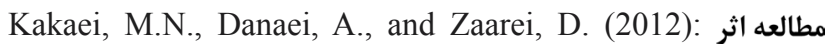

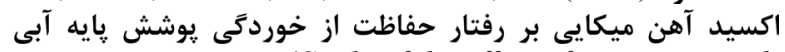
سيليكاتى غنى از روى ايه آى (Study of the effect of mica iron oxide on the corrosion protection behavior of zinc-rich aqueous silicate base coatings). Journal of New processes in materials engineering, 7, 3, 25-36. (In Persian: with English abstract).

Kalenda, P., Kalendová, A., Štengl, V., Antoš, P., Šubrt, J., Kváča, Z., and Bakardjieva, S. (2004): Properties of surface-treated mica in anticorrosive coatings. Progress in Organic Coatings, 49, 2, 137-145. https://doi.org/10.1016/j. porgcoat.2003.09.003.

Lagoeiro, L.E. (1998): Transformation of magnetite to hematite and its influence on the dissolution of iron oxide minerals. Journal of Metamorphic Geology, 16, 3, 415-423. https://doi.org/10.1111/j.1525-1314.1998.00144.x.

Ravi, B.P., Venkatesha, B., Krishna, S.J.G., Patil, M.R., and Kumar, P.S. (2015): Beneficiation of Micaceous Iron Oxide from Veldurthi Area, Kurnool, AP, India. J Powder Metall Min, 4, 133, 2. http://dx.doi.org/10.4172/21689806.1000133.

Tamboura, M., Mikhailova, A.M., and Jia, M.Q. (2013): Development of heat-resistant anticorrosion urethane siloxane paints. Journal of Coatings Technology and Research, 10, 3, 381-396. https://doi.org/10.1007/s11998-012-9464-0.

Tanriverdi, M., Sen, S., and Ciçek, T. (2018): Micaceous iron oxide production by application of magnetic separation. Physicochemical Problems of Mineral Processing, 54, 35 44. http://dx.doi.org/10.5277/ppmp1845.

Tian, G., Wang, W., Wang, D., Wang, Q., and Wang, A. (2017): Novel environment friendly inorganic red pigments based on attapulgite. Powder Technology, 315, 60-67. https://doi. org/10.1016/j.powtec.2017.03.044.

Vapur, H., and Top, S. (2016): Improving of quality properties of the specularite ore (in Turkish). Çukurova Univ. J. Faculty Eng. Architec, 31, 1, 293-300.

Villalba, J.C., Constantino, V.R., and Anaissi, F.J. (2010): Iron oxyhydroxide nanostructured in montmorillonite clays: Preparation and characterization. Journal of Colloid and Interface Science, 349, 1, 49-55. https://doi.org/10.1016/j. jcis.2010.04.057.

Wang, W.Z., Zhang, J.R., and Yang, C.G. (2011): Experimental research on beneficiation process for a specularite ore. Advanced Materials Research, 304, 387-390. https://doi. org/10.4028/www.scientific.net/AMR.304.387.

Yang, H.Q., Zhang, Q., Tu, S.S., Wang, Y., Li, Y.M., and Huang, Y. (2016): A study on effects of elastic stress on protective properties of marine coatings on mild steel in artificial seawater. Progress in Organic Coatings, 99, 6171. https://doi.org/10.1016/j.porgcoat.2016.05.009.

Zheng, X., Wang, Y., and Lu, D. (2017): Study on buildup of fine weakly magnetic minerals on matrices in high gradient magnetic separation. Physicochemical Problems of Mineral Processing, 53, 45-51. http://dx.doi.org/10.5277/ ppmp170108. 


\section{SAŽETAK}

\section{Kartiranje liskunaste željezne rude i izrada primjenjivih industrijskih standarda}

Svrha je ovoga istraživanja odrediti prikladnu metodu za oplemenjivanje liskunaste željezne rude te izrada standarda primjenjivih u industriji. Nakon utvrđivanja karakteristika uzoraka (s XRF, XRD, mineraloškim analizama) provedena su ispitivanja gravitacijskom i magnetskom separacijom. Kvarc i hematit glavni su minerali liskunastih hematitnih ruda. Udio silicija kao glavne nečistoće varira od $10 \%$ do 68 \%. Ukupni sadržaj željeza u uzorcima također varira od $15 \%$ do 62 $\%$. Plakalica i koncentracijski stol nisu dali dobre rezultate u obogaćivanju liskunastoga hematita za postizanje standarda njegove specifične primjene. No, gravitacijska koncentracija spiralom veličine zrna -200 i -300 $\mu$ m rezultirala je kvalitetom koncentrata željeza od 62,34 odnosno 64,84 \%. Vrijednosti iskorištenja bile su 13,50 odnosno 12,6o \%. Stoga ni spirala nije dala dobar rezultat u obogaćivanju liskunaste željezne rude. Visokointenzivna magnetska separacija (1,2 T) rezultirala je kvalitetom koncentrata od 65,98 \% i iskorištenjem od 88,35\%. Eksperimentalni dizajn prema Taguchiju s obzirom na povećanje kvalitete ili iskorištenja pokazao je da za povećanje iskorištenja frekvencija dodavača, brzina bubnja i kut separacijskoga noža trebaju biti na $6,5 \mathrm{~Hz}, 95 \mathrm{o} / \mathrm{min}$ i $20^{\circ}$. Međutim, za obogaćivanje liskunaste željezne rude s prioritetom povećanja kvalitete koncentrata frekvencija dodavača, brzina bubnja i kut separacijskoga noža trebaju biti $2,5 \mathrm{~Hz}, 135 \mathrm{o} / \mathrm{min}$, odnosno $60^{\circ}$.

\section{Ključne riječi:}

spekularit, liskunasta željezna ruda, magnetska separacija, gravitacijska separacija, Taguchi

\section{Author's contribution}

Alireza Abedi (MSc student of mineral processing) provided the tests and presentation of the results. Ataallah Bahrami (Associate Professor, Minerals Processing) proposed ideas and advised the research. Sajjad Chehreghani (Assistant Professor, Minerals Processing) proposed ideas and advised the research. Masoud Ghadri (MSc of Mining Engineering) proposed ideas and provided the samples. Fatemeh Kazemi (PhD student of mineral processing) performed tests, provided reports and wrote the article. 